\title{
Combining ability and heterosis as influenced by male-sterility inducing cytoplasms in sorghum [Sorghum bicolor (L.) Moench]
}

\author{
Belum V. S. Reddy $\cdot$ S. Ramesh • \\ P. Sanjana Reddy $\cdot$ B. Ramaiah
}

Received: 13 September 2004 / Accepted: 22 September 2006/ Published online: 17 October 2006

(C) Springer Science+Business Media B.V. 2006

\begin{abstract}
An investigation was carried out to assess the efficiency of $\mathrm{A}_{2}$ cytoplasmic-nuclear male-sterility (CMS) system in comparison to the widely used $\mathrm{A}_{1}$ cytoplasm in terms of general combining ability ( $g c a$ ) effects of male-sterile (A-) lines and mean performance, specific combining ability (sca) effects and mid-parent heterosis of hybrids for days to $50 \%$ flowering, plant height and grain yield at International Crops Research Institute for the Semi-Arid Tropics, Patancheru, Andhra Pradesh, India in 2001 and 2002 rainy seasons. The material for the study consisted of six pairs of iso-nuclear, allo-plasmic $\left(\mathrm{A}_{1}\right.$ and $\left.\mathrm{A}_{2}\right)$ A-lines and 36 iso-nuclear hybrids produced by crossing these A-lines with three dual restorer (R-) lines. The results revealed that cytoplasm and its first-order interaction with year, R- and A-lines did not appear to contribute to variation in isonuclear hybrids for plant height and grain yield. Cytoplasm had limited effect on gca effects of Alines and on sca effects and mid-parent heterosis of iso-nuclear hybrids for days to $50 \%$ flowering, plant height and grain yield. The mean days to $50 \%$ flowering, plant height and grain yield of $\mathrm{A}_{2}$
\end{abstract}

B. V. S. Reddy $(\bowtie) \cdot$ S. Ramesh · P. S. Reddy •

B. Ramaiah

Global Theme on Crop Improvement, International Crops Research Institute for the Semi-Arid Tropics (ICRISAT), Patancheru 502 324, Andra Pradesh, India

e-mail: b.reddy@cgiar.org cytoplasm-based hybrids were comparable with those of widely used $\mathrm{A}_{1}$ cytoplasm-based hybrids. The relative frequency of the occurrence of the $\mathrm{A}_{1^{-}}$and $\mathrm{A}_{2}$-based hybrids with significant sca effects and mid-parent heterosis indicated that $\mathrm{A}_{2}$ CMS system is as efficient as $A_{1}$ with a slight edge over $\mathrm{A}_{1}$ for commercial exploitation. The implications of these results are discussed in relation to opportunities for broadening not only cytoplasm base but also nuclear genetic base of both the hybrid parents.

Keywords Sorghum $\cdot$ Cytoplasmic-nuclear male-sterility · Iso-nuclear · Allo-plasmic · Combining ability $\cdot$ Heterosis

\section{Introduction}

Sorghum [Sorghum bicolor (L.) Moench] is the fifth important crop after wheat, maize, rice and barley and is widely cultivated in the semi-arid regions of the world. Hybrid cultivar development in sorghum has been possible due to the discovery of workable cytoplasmic-nuclear malesterility (CMS) (Stephens and Holland 1954) designated as $\mathrm{A}_{1}$. Large numbers of CMS-based hybrids have been developed and released/marketed in countries with a well developed seed industry including India and China. The increased sorghum productivity in China (by $>2 \mathrm{tha}^{-1}$ ) and 
India (by $>0.5 \mathrm{t} \mathrm{ha}^{-1}$ ) has been largely attributed to the adoption of hybrids (Deb et al. 2004). The commercial hybrids produced so far all over the globe are based on $\mathrm{A}_{1} \mathrm{CMS}$ system. However, based on the experience in other crops, the chances of these $\mathrm{A}_{1}$ cytoplasm-based hybrids becoming vulnerable to unforeseen insect pests and/or diseases outbreak cannot be ruled out. For instance, outbreak of corn leaf blight disease in 1970 devastated the corn hybrids possessing Texas (T) cytoplasm (Tatum 1971). In addition to cytoplasm uniformity in the hybrids, use of single cytoplasm restricts nuclear genetic diversity of male-sterile (A-) as well as restorer (R-) lines. Therefore, to prevent such eventualities and to broaden the genetic base, the need for diversification of CMS base of sorghum hybrids was felt long back and as a result, several non-milo CMS systems were identified and developed (Schertz 1994) for use in hybrid breeding programs. However, utilization of these non-milo CMS systems at commercial level depends on factors such as stability of male-sterility, restorer gene frequency in the germplasm, effect of malesterility inducing cytoplasm on agronomic traits, and the availability of commercially viable heterosis (Reddy et al. 2005).

The $\mathrm{A}_{2}$ system, originally reported in IS 12662C (SC 171) line, from Caudatum Nigricans group belonging to subseries caffra (Schertz and Ritchey 1978) is stable and sufficient number of restorers are available on this cytoplasm (Reddy et al. 2005). However, its measurable effects on A-lines for their general combining ability ( $\mathrm{cca}$ ) effects and on specific combining ability ( $s c a$ ) effects and expression of heterosis of the hybrids is not clearly established, although such studies are important in CMS-based hybrid breeding programs. In pursuit of exploitation of alternate cytoplasm(s) for accomplishing the required diversification, agronomic performance of CMS-based hybrids cannot be compromised. Therefore, before large-scale exploitation of $\mathrm{A}_{2}$ cytoplasm for hybrid cultivar development, it should be at least comparable, if not superior to the currently used $A_{1}$ cytoplasm. The results on the cytoplasmic effects in the past studies (Kishan and Borikar 1988; Maves and Atkins 1988; Secrist and Atkins 1989) are not only inconsistent, but also the test hybrids based on alternate CMS systems in sorghum were not in common nuclear genetic background. Therefore, it is possible that the variable cytoplasm effects observed in such studies might be confounded with nuclear genetic differences. To discern the effect of different CMS systems on gca effects of A-lines and mean performance, sca effects and heterosis of hybrids, they must be in iso-nuclear background. While such studies on cytoplasm effects on mean performance of A-lines and hybrids involving iso-nuclear but allo-plasmic A-lines and common $\mathrm{R}$-lines are limited in sorghum (Williams-Alanis and Rodriguez-Herrera 1992; Rodriguez-Herrera et al. 1993; Williams-Alanis et al. 1993; Moran and Rooney 2003), studies on the role of cytoplasm on $g c a$ effects of A-lines and on sca effects and heterosis of hybrids in sorghum are lacking. The assessment of $g c a$ effects of hybrid parents is important to judge their suitability for developing hybrids, as the mean performance of parental lines need not always be a good indicator of their gca effects. Further, the studies on the effects of cytoplasm on hybrid mean performance for various traits are although useful, as reported by Moran and Rooney (2003), sca effects of isonuclear hybrids would be more revealing since they reflect differential interaction of cytoplasms with nuclear genes of A-lines as well as R-lines and it is this interaction in higher magnitude and favorable direction that results in superior hybrid performance with commercially viable levels of heterosis.

In the present study, the effects of $\mathrm{A}_{2}$ cytoplasm in comparison to $\mathrm{A}_{1}$ on mean performance, combining ability and heterosis for agronomic traits were assessed using iso-nuclear, allo-plasmic A-lines and hybrids derived by crossing these A-lines with perfect dual R-lines.

\section{Materials and methods}

The materials for the study consisted of six isonuclear allo-plasmic $\left(\mathrm{A}_{1}\right.$ and $\left.\mathrm{A}_{2}\right)$ A-lines in six different nuclear genetic backgrounds-ICSA 17 , ICSA 37, ICSA 38, ICSA 42, ICSA 88001 and ICSA 88005 and three dual R-lines-ICSR 92003, ICSR 93001 and ICSR 93031. These were 
developed at ICRISAT, Patancheru, India in a program to diversify the CMS-base of hybrid seed parents. While the six A-lines used in the study were originally developed in $A_{1}$ cytoplasm from improved germplasm crosses derivatives during 1980-1990 (Reddy et al. 2005), the dual R-lines were developed through either direct landrace selection or through their cross derivatives during early 1990s. These A-lines have been used for the production of commercial hybrid sorghums. The $A_{2}$ versions of the six A-lines were developed through repeated back crossing of $A_{1}$ maintainer (B-) lines to known $\mathrm{A}_{2}$ cytoplasm source. The Alines represent wide range of variation for days to $50 \%$ flowering (66-73 days), plant height (1.2$1.9 \mathrm{~m})$ and grain yield potential $\left(2.5-4.0 \mathrm{t} \mathrm{ha}^{-1}\right)$ (Table 1). Similarly, the R-lines are also diverse for days to $50 \%$ flowering (67-75 days), plant height $(1.8-3.1 \mathrm{~m})$ and grain yield potential $(2.8-$ $4.9 \mathrm{t} \mathrm{ha}^{(1}$ ) (Table 1). As the seed parents and restorers have diverse geographical (India, USA, Sudan and Ethiopia) and racial (durra, caudatum, guinea-caudatum and kafir-durra) origins and represent wide variation for adaptive trait (days to $50 \%$ flowering), and yield potential, it was expected that they significantly differ for combining ability and heterosis, considering strong association between mean performance of parents and their gca effects and their hybrid performance (Quinby and Karper 1946; Murty 1991, 1992; Bhavsar and Borikar 2002) and also strong association between parental diversity and hybrid superiority (Rao 1970; Shinde et al. 1983; Rana et al. 1985; Rana and Murty 1978).

The seed parents were crossed with the three dual $\mathrm{R}$-lines in a line $\times$ tester mating design to produce 36 hybrid combinations in $A_{1}$ and $A_{2}$ CMS backgrounds. These hybrid combinations (hybrid trial) were evaluated in a split-split-plot design with three replications with $\mathrm{R}$-lines in main plots, A-lines in sub plots and cytoplasms in sub-sub plots during 2001 and 2002 rainy seasons. The B-lines of the respective six A-lines and the three R-lines (parental trial) were evaluated in randomized complete block design with three replications in a contiguous block. In both hybrid and parental trials, each entry was planted in two rows of $4 \mathrm{~m}$ length with a spacing of $75 \mathrm{~cm}$ between rows and $10 \mathrm{~cm}$ between plants within a row at experimental fields of ICRISAT, Patancheru, India. All the recommended agronomic practices were followed to raise a healthy crop.

Table 1 Pedigree and agronomic characteristics of sorghum hybrid parents (A- and R-lines) used in developing hybrids

\begin{tabular}{llll}
\hline $\begin{array}{l}\text { Hybrid } \\
\text { parents }\end{array}$ & Pedigree & $\begin{array}{l}\text { Days to 50\% } \\
\text { flowering }\end{array}$ & $\begin{array}{l}\text { Plant } \\
\text { height } \\
(\mathrm{m})\end{array}$ \\
\hline
\end{tabular}

\begin{tabular}{|c|c|c|c|c|}
\hline \multicolumn{5}{|l|}{ A-lines } \\
\hline $\begin{array}{l}\mathrm{ICSA} / \mathrm{B} \\
17\end{array}$ & {$[($ BTx $623 \times 1807$ B $) \times$ B-lines bulk $]-18-1-1$} & 70 & 1.2 & 4.0 \\
\hline $\begin{array}{l}\text { ICSA/B } \\
37\end{array}$ & {$[($ BTx $623 \times(($ SC 108-3 × GPR 148)-18-4-1) $) \times$ B-lines bulk]-5-1-2-5 } & 73 & 1.3 & 3.7 \\
\hline $\begin{array}{l}\mathrm{ICSA} / \mathrm{B} \\
38\end{array}$ & [(BTx $623 \times(($ SC 108-3 × GPR 148)-18-4-1) $) \times$ B-lines bulk]-5-1-3-5 & 72 & 1.3 & 3.5 \\
\hline $\begin{array}{l}\mathrm{ICSA} / \mathrm{B} \\
42\end{array}$ & {$[($ BTx $623 \times(($ SC 108-3 × GPR 148)-18-4-1) $) \times$ B-lines bulk]-5-3-6-3 } & 70 & 1.3 & 3.5 \\
\hline $\begin{array}{r}\text { ICSA/B } \\
88001\end{array}$ & $\begin{array}{l}{[((((\text { BTx } 623 \times \text { CSV 4) } \times \text { B-lines bulk })-7-2-2) \times \text { Diallel 346-1 }) \times \text { Diallel }} \\
\quad 7-2-862]-1-1\end{array}$ & 66 & 1.9 & 4.0 \\
\hline $\begin{array}{r}\mathrm{ICSA} / \mathrm{B} \\
88005\end{array}$ & $\begin{array}{l}{[((((\text { BTx } 624 \times \text { UChV 2) } \times \text { B-lines bulk })-5-1-1-1) \times(((\mathrm{BTx}} \\
\quad 623 \times \mathrm{UChV} 2) \times \text { B-lines bulk })-10-1-4)) \times \mathrm{DM} 50]-1-1-1-1\end{array}$ & 66 & 1.4 & 2.5 \\
\hline \multicolumn{5}{|c|}{ Dual R-lines } \\
\hline $\begin{array}{l}\text { ICSR } \\
92003\end{array}$ & $\begin{array}{l}{[(\text { IS } 23528 \times(((\text { IS } 12622 \mathrm{C} \times 555) \times((\text { IS 3612C } \times 2219 B)-5-1 \times \text { E 35- }} \\
1))-5-2)) \times \text { PS 29154]-4-2-2-4 }\end{array}$ & 67 & 1.9 & 4.3 \\
\hline $\begin{array}{l}\text { ICSR } \\
93001\end{array}$ & $\begin{array}{l}{[(\text { IS } 23528 \times(((\text { IS } 12622 \mathrm{C} \times 555) \times((\text { IS } 3612 C \times 2219 B)-5-1 \times \text { E 35- }} \\
\quad 1))-5-2)) \times \text { PS 29159]-4-2-1-1 }\end{array}$ & 68 & 1.8 & 4.9 \\
\hline $\begin{array}{l}\text { ICSR } \\
93031\end{array}$ & M $35-1-36$ & 75 & 3.1 & 2.8 \\
\hline
\end{tabular}


To ensure maximum expression, the crop was provided with protective irrigation. In both the experiments, the data on days to $50 \%$ flowering, plant height (m) and seed set (\%) upon selfing and open pollination were recorded on five randomly selected plants in each entry and in each replication, while the data on grain yield were taken on whole-plot basis (border effects are assumed random/minimum) in both hybrid and parental trials.

\section{Statistical analyses}

The computed average values for days to $50 \%$ flowering, plant height and grain yield in both hybrid and parental trials were subjected to statistical analyses. The data on seed set (\%) upon selfing and open pollination were not statistically analyzed as all the hybrids irrespective of cytoplasm background showed over $90 \%$ seed set and practically there was no variation in $\%$ seed set among the hybrids. The combined analysis of variance was carried out for days to $50 \%$ flowering, plant height and grain yield considering cytoplasms, A- and R-lines as fixed factors following split-split-plot design in hybrid trial. Considering that year-to-year variation predominantly stem from seasonal variation caused by changes in weather variables which are highly dynamic and not known in advance (Annicchiarico 2002), years were regarded as random factor. The homogeneity of error variances in the trials conducted in 2 years, as revealed by Bartlett's test (Bartlett 1937) provided statistical validity to carry out combined analysis of variance. Appropriate ' $F$ ' tests were conducted to test the significance of A-, R-lines, cytoplasm and their first- and second-order interactions at probability levels of 0.05 and 0.01 .

Combining ability analysis was performed, separately for individual years using hybrid trial data according to Kempthorne (1957). Cytoplasm differences for $g c a$ effects of iso-nuclear A-lines and sca effects of iso-nuclear hybrids were tested using least significant difference calculated based on the standard error of mean for cytoplasm factor from the year-wise analysis of variance. The parental (B- and R-line) mean performance estimated from parental trial was used to calculate mid-parent heterosis for days to $50 \%$ flowering, plant height and grain yield in individual years as:

Mid - parent heterosis of a hybrid $=(\bar{A}-\bar{a}) / \bar{a}$,

where, $\bar{A}=$ mean performance of the hybrid in question; $\bar{a}=$ mean performance of B-line of the respective A-line ( mean performance of R-line divided by 2 . The estimation of mid-parent heterosis requires hybrid and parental mean values, which were obtained from two different trials. The similarity of environmental effects in two different trials is essential for such a joint analysis. The homogeneity of error variances of hybrid and parental trials, as revealed by ' $F$ ' test $(P>0.05)$ provided statistical validity for the use of hybrid and parental mean values for the estimation of mid-parent heterosis. The performances of cytoplasm differences for mid-parent heterosis of iso-nuclear hybrids (considering $\mathrm{A}_{1}$ and $\mathrm{A}_{2}$-based hybrids as two groups) were tested using two-sample paired ' $t$ ' test. All the statistical analyses were carried out using GENSTAT-5th edition package of Rothamsted Experiment Station, UK.

\section{Results and discussion}

Variances components

It follows from the combined analysis of variance (Table 2) that both A-lines (nuclear genotype) and R-lines are significantly different from each other for all the traits, justifying the selection of the hybrid parents (A- and R-lines) for the study. The temporal variation (years) did not seem to contribute to year $\times$ cytoplasm, year $\times$ R-line interactions for grain yield, despite highly significant mean squares due to years, which predominantly stem from seasonal variation caused by dynamic changes in weather variables from year to year (Annicchiarico 2002). However, seasonal changes over the years did have significant influence on the performance of A-lines over the years for grain yield as supported by significant mean squares due to year $\times$ A-lines interaction. Thus, A-lines were 
Table 2 Combined analysis of variance of sorghum iso-nuclear allo-plasmic male-sterile lines, their common restorers and hybrids, 2001 and 2002 rainy seasons, ICRISAT, Patancheru

\begin{tabular}{|c|c|c|c|c|}
\hline \multirow[t]{2}{*}{ Source of variation } & \multirow[t]{2}{*}{ df } & \multicolumn{3}{|l|}{ Mean sum of squares } \\
\hline & & Days to $50 \%$ flowering & Plant height (m) & Grain yield $\left(\mathrm{t} \mathrm{ha}^{-1}\right)$ \\
\hline Replication & 2 & 2.23 & 0.07 & 0.20 \\
\hline Year & 1 & $247.04 * *$ & $1.08 *$ & $5.87 *$ \\
\hline Residual & 4 & 2.25 & 0.09 & 0.80 \\
\hline R-line & 2 & $123.63^{* *}$ & $18.25 * *$ & $34.17 * *$ \\
\hline Year $\times$ R-line & 2 & 2.89 & 0.21 & 3.58 \\
\hline Residual & 8 & 10.37 & 0.05 & 1.33 \\
\hline A-line & 5 & $97.38^{* *}$ & $0.11 * *$ & $1.29 *$ \\
\hline Year $\times$ A-line & 5 & 5.95 & 0.01 & $2.40 * *$ \\
\hline R-line $\times$ A-line & 10 & $20.69 * *$ & 0.05 & $2.96 * *$ \\
\hline Year $\times$ R-line $\times$ A-line & 10 & $8.77 * *$ & 0.01 & $2.17 * *$ \\
\hline Residual & 60 & 2.75 & 0.02 & 0.52 \\
\hline Cytoplasm & 1 & $8.56^{*}$ & 0.01 & 0.01 \\
\hline Year $\times$ cytoplasm & 1 & 3.38 & 0.04 & 0.05 \\
\hline R-line $\times$ cytoplasm & 2 & 3.19 & 0.01 & 0.35 \\
\hline A-line $\times$ cytoplasm & 5 & $7.16^{* *}$ & 0.01 & 0.49 \\
\hline Year $\times$ R-line $\times$ cytoplasm & 2 & $6.89 * *$ & 0.01 & 1.21 \\
\hline Year $\times$ A-line $\times$ cytoplasm & 5 & $11.06^{* *}$ & 0.02 & 1.05 \\
\hline R-line $\times$ A-line $\times$ cytoplasm & 10 & $6.39 * *$ & 0.02 & 0.66 \\
\hline Year $\times$ R-line $\times$ A-line $\times$ cytoplasm & 10 & $10.85^{* *}$ & 0.02 & 0.52 \\
\hline Residual & 72 & 1.44 & 0.02 & 1.18 \\
\hline
\end{tabular}

* Significant at $P=0.05$ level

** Significant at $P=0.01$ level

more responsive to seasonal changes over the years than R-lines for grain yield.

The contribution of cytoplasms and their firstorder interaction with A-line and second-order interaction with $\mathrm{A}-$, $\mathrm{R}$-line and year to the variation of iso-nuclear hybrids for days to $50 \%$ flowering was significant, suggesting significant overall influence of cytoplasm on the responses of hybrids for days to $50 \%$ flowering (Table 2). However, non-significant mean squares due to cytoplasm for plant height and grain yield indicated absence of cytoplasm effects on the expression of hybrids for these two traits. The absence of cytoplasm $\left(\mathrm{A}_{1}\right.$ and $\left.\mathrm{A}_{2}\right)$ effects as well as their interaction with the environments for grain yield was also reported by Williams-Alanis and Rodriguez-Herrera (1994a).

The significant mean squares due to $\mathrm{R}$ line $\times$ A-line interaction for days to $50 \%$ flowering and grain yield suggested significant variation of sca effects of hybrids and the sca effects are sensitive to seasonal changes over the years as indicated from significant mean squares due to year $\times$ R-line $\times$ A-line interaction.
Cytoplasm effects on $g c a$ effects

In hybrid breeding programs, the assessment of gca effects of different breeding lines is important to judge their suitability for developing hybrids, as mean performance of parental lines need not always be correlated with their gca effects. Also, gca effects reflect true genotypic value of a line, as these are estimated as mean effect of a line in a series of crosses. Thus, higher the gca of a line, higher is the average performance of its hybrids. Although in this study, most of the A-lines manifested significant gca effects for days to $50 \%$ flowering in both the cytoplasms $\left(\mathrm{A}_{1}\right.$ and $\mathrm{A}_{2}$ ) backgrounds during both 2001 and 2002 rainy seasons, cytoplasm did not appear to have noticeable influence on $g c a$ effects, with significant cytoplasm difference detected only in one nuclear genetic background (ICSA 38) during 2001 rainy season (Table 3). Despite significant differences among A-lines for all the three traits (Table 2), gca effects of most A-lines within each of the cytoplasms were not significant for plant height and grain yield, suggesting that mean performance 
Table 3 Estimates of $g c a$ effects of iso-nuclear sorghum A-lines as influenced by their cytoplasm, 2001 and 2002 rainy seasons, ICRISAT, Patancheru

\begin{tabular}{|c|c|c|c|c|c|c|c|c|c|c|c|c|}
\hline \multirow[t]{3}{*}{ A-lines } & \multicolumn{4}{|c|}{ Days to $50 \%$ flowering } & \multicolumn{4}{|c|}{ Plant height (m) } & \multicolumn{4}{|c|}{ Grain yield ( $\left.\mathrm{t} \mathrm{ha}^{-1}\right)$} \\
\hline & \multicolumn{2}{|l|}{2001} & \multicolumn{2}{|l|}{2002} & \multicolumn{2}{|l|}{2001} & \multicolumn{2}{|l|}{2002} & \multicolumn{2}{|l|}{2001} & \multicolumn{2}{|l|}{2002} \\
\hline & $\mathrm{A}_{1}$ & $\mathrm{~A}_{2}$ & $\mathrm{~A}_{1}$ & $\mathrm{~A}_{2}$ & $\mathrm{~A}_{1}$ & $\mathrm{~A}_{2}$ & $\mathrm{~A}_{1}$ & $\mathrm{~A}_{2}$ & $\mathrm{~A}_{1}$ & $\mathrm{~A}_{2}$ & $\mathrm{~A}_{1}$ & $\mathrm{~A}_{2}$ \\
\hline ICSA 17 & -0.94 & 0.07 & 0.04 & -0.30 & -0.06 & $-0.13 * *$ & $-0.12 * *$ & $-0.11^{*}$ & 0.27 & -0.15 & $-0.53 *$ & -0.23 \\
\hline ICSA 37 & $1.95 * *$ & $2.39 * *$ & $1.37 * *$ & $2.37 * *$ & -0.02 & 0.02 & 0.01 & 0.04 & 0.02 & 0.05 & $0.37^{\mathrm{a}}$ & -0.38 \\
\hline ICSA 38 & $1.62 * *$ & $-0.16^{\mathrm{a}}$ & $1.93 * *$ & $2.15^{* *}$ & -0.05 & 0.05 & 0.01 & 0.01 & 0.28 & 0.27 & 0.44 & 0.12 \\
\hline ICSA 42 & $-1.27 * \mathrm{a}$ & $2.84 * *$ & 0.26 & -0.07 & 0.05 & 0.04 & 0.02 & -0.04 & -0.18 & -0.68 & -0.23 & 0.11 \\
\hline ICSA 88001 & -0.49 & -0.82 & $-1.63 * *$ & $-1.52 * *$ & 0.04 & 0.03 & $0.09 *$ & 0.06 & -0.55 & 0.03 & $0.55^{*}$ & 0.50 \\
\hline ICSA 88005 & $-2.82 * *$ & $-2.38 * *$ & $-2.41 * *$ & $-2.19 * *$ & -0.05 & $0.09 *^{\mathrm{a}}$ & 0.06 & -0.03 & 0.29 & 0.35 & $-0.59 *$ & -0.14 \\
\hline $\mathrm{SE} \pm(\mathrm{gi})$ & 0.53 & & 0.44 & & 0.05 & & 0.04 & & 0.36 & & 0.26 & \\
\hline $\mathrm{CD}\left(\mathrm{A}_{1}-\mathrm{A}_{2}\right)(P=0.05)$ & 1.49 & & 1.22 & & 0.13 & & 0.12 & & 1.00 & & 0.74 & \\
\hline
\end{tabular}

* Significant at $P=0.05$ level

** Significant at $P=0.01$ level

a Significant cytoplasm differences

of A-lines need not always reflect their gca effects for these two traits. Significant cytoplasm differences were detected only in one nuclear genetic background for plant height (in ICSA 88005) during 2001 rainy season and for grain yield (in ICSA 37) during 2002 rainy season. However, the magnitude of these cytoplasm differences was small enough to have any practical significance. Thus, the study clearly showed that cytoplasm had limited influence on $g c a$ effects for all the traits investigated. It is important to note that the results of the present investigation apply only to the material used in the study, as A-lines are deliberate selections and the analysis is based on fixedeffects model. The absence of cytoplasm $\left(\mathrm{A}_{1}\right.$ and $A_{2}$ ) influence on $g c a$ effects for grain yield was also reported by Williams-Alanis and RodriguezHerrera (1994b).

Cytoplasm effects on hybrid mean performance

The results revealed absence of significant cytoplasm differences in hybrid mean performance for any of the traits under investigation during both 2001 and 2002 rainy seasons, except for days to $50 \%$ flowering during 2001 rainy season, when average performance of $\mathrm{A}_{1^{-}}$and $\mathrm{A}_{2}$-based hybrids were examined (Table 4). However, when hybrid mean performance of individual allo-plasmic hybrids were examined, significant cytoplasm effects were evident for all the traits, although no definite pattern of association of these traits with a particular cytoplasm was observed. For instance, the hybrids, ICSA $17 \times$ ICSR 92003 (during 2001 and 2002 rainy seasons) and ICSA $42 \times$ ICSR 93031 (during 2001 rainy season) in $\mathrm{A}_{1}$ CMS background were significantly early by 2-3 days compared to those in $\mathrm{A}_{2}$ background. On the contrary, the hybrids, ICSA $38 \times$ ICSR 93031 and ICSA $88001 \times$ ICSR 92003 (during 2001 and 2002 rainy seasons) and ICSA $42 \times$ ICSR 93031 (during 2002 rainy season) in $\mathrm{A}_{1}$ CMS background were significantly late by 1-2 days compared to those in $\mathrm{A}_{2}$ CMS background. The differences in days to $50 \%$ flowering between $A_{1}$ and $A_{2}$ cytoplasm-based hybrids by 2-3 days are of little practical significance. These results are in conformity with those of Moran and Rooney (2003).

$\mathrm{A}_{1}$ and $\mathrm{A}_{2}$ cytoplasm-based hybrids had comparable grain yield potential when average of 36 hybrids was considered during both 2001 and 2002 rainy seasons. Secrist and Atkins (1989) also found similar grain yield potential of $A_{1}$ and $A_{2}$ cytoplasm-based hybrids. These results are not in conformity with some of the reports. For example, while Kishan and Borikar (1989) reported superiority of $\mathrm{A}_{2}$ cytoplasm-based hybrids over $\mathrm{A}_{1}$-based hybrids, Maves and Atkins (1988) observed lower grain yield potential of $\mathrm{A}_{2}$ cytoplasm-based hybrids when compared to $\mathrm{A}_{1}$-based 
Table 4 Mean performance of iso-nuclear sorghum hybrids as influenced by male-sterility inducing cytoplasm of their A-lines, 2001 and 2002 rainy seasons, ICRISAT, Patancheru

\begin{tabular}{|c|c|c|c|c|c|c|c|c|c|c|c|c|}
\hline \multirow[t]{3}{*}{ Hybrid } & \multicolumn{4}{|c|}{$\begin{array}{l}\text { Days to } 50 \% \\
\text { flowering }\end{array}$} & \multicolumn{4}{|c|}{ Plant height $(\mathrm{m})$} & \multicolumn{4}{|c|}{ Grain yield $\left(\mathrm{t} \mathrm{ha}^{-1}\right)$} \\
\hline & \multicolumn{2}{|c|}{2001} & \multicolumn{2}{|c|}{2002} & \multicolumn{2}{|c|}{2001} & \multicolumn{2}{|c|}{2002} & \multicolumn{2}{|l|}{2001} & \multicolumn{2}{|l|}{2002} \\
\hline & $\mathrm{A}_{1}$ & $\mathrm{~A}_{2}$ & $\mathrm{~A}_{1}$ & $\mathrm{~A}_{2}$ & $\mathrm{~A}_{1}$ & $\mathrm{~A}_{2}$ & $\mathrm{~A}_{1}$ & $\mathrm{~A}_{2}$ & $\mathrm{~A}_{1}$ & $\mathrm{~A}_{2}$ & $\mathrm{~A}_{1}$ & $\mathrm{~A}_{2}$ \\
\hline ICSA $17 \times$ ICSR 93001 & 68 & 68 & 68 & 68 & 2.1 & 2.1 & 2.1 & 2.1 & 5.82 & 5.55 & 4.46 & $5.46^{\mathrm{a}}$ \\
\hline ICSA $17 \times$ ICSR 92003 & $65^{\mathrm{a}}$ & 68 & 69 & 69 & 2.0 & 2.0 & 2.2 & 2.1 & 6.03 & 5.68 & 6.54 & 6.45 \\
\hline ICSA $17 \times$ ICSR 93031 & 63 & 64 & 68 & 68 & 3.0 & 2.8 & 3.0 & 3.1 & 5.12 & 4.47 & 4.63 & 4.64 \\
\hline ICSA 37 × ICSR 93001 & 70 & 71 & $69^{\mathrm{a}}$ & 71 & 2.2 & 2.2 & 2.2 & 2.1 & 5.97 & 5.50 & $6.89^{\mathrm{a}}$ & 5.54 \\
\hline ICSA $37 \times$ ICSR 92003 & 69 & 69 & 73 & 73 & 2.1 & 2.1 & 2.3 & 2.4 & 5.40 & 5.86 & 6.58 & 6.52 \\
\hline ICSA $37 \times$ ICSR 93031 & 67 & 67 & 68 & 69 & 2.9 & 3.1 & 3.2 & 3.3 & 4.85 & 4.95 & $4.87^{\mathrm{a}}$ & 4.03 \\
\hline ICSA $38 \times$ ICSR 93001 & 69 & 68 & 71 & 71 & 2.1 & 2.3 & 2.2 & 2.3 & 5.80 & 5.68 & 6.71 & 6.12 \\
\hline ICSA $38 \times$ ICSR 92003 & 68 & 67 & 72 & 72 & 2.1 & 2.2 & 2.3 & 2.2 & 5.99 & 6.14 & 6.48 & 6.03 \\
\hline ICSA $38 \times$ ICSR 93031 & 66 & $63^{\mathrm{a}}$ & 69 & 68 & 2.9 & 3.0 & 3.3 & 3.2 & 5.21 & 5.15 & 5.34 & 5.44 \\
\hline ICSA $42 \times$ ICSR 93001 & 67 & 67 & 68 & 68 & 2.3 & 2.2 & 2.2 & 2.1 & 6.02 & 6.07 & 5.75 & $7.03^{\mathrm{a}}$ \\
\hline ICSA $42 \times$ ICSR 92003 & 64 & 64 & 69 & 70 & 2.1 & 2.1 & 2.2 & 2.2 & 6.48 & 6.24 & 5.78 & 6.50 \\
\hline ICSA $42 \times$ ICSR 93031 & $64^{\mathrm{a}}$ & 67 & 69 & $67^{\mathrm{a}}$ & 3.0 & 3.1 & $3.4^{\mathrm{a}}$ & 3.2 & 3.11 & 1.80 & $5.01^{\mathrm{a}}$ & 4.04 \\
\hline ICSA $88001 \times$ ICSR 93001 & 66 & 68 & 66 & 66 & 2.3 & 2.3 & 2.3 & 2.2 & 4.73 & 6.14 & 6.56 & 6.81 \\
\hline ICSA $88001 \times$ ICSR 92003 & 66 & $65^{\mathrm{a}}$ & 68 & 68 & 2.0 & 2.1 & 2.4 & 2.4 & 5.43 & 4.97 & $6.74^{\mathrm{a}}$ & 5.86 \\
\hline ICSA $88001 \times$ ICSR 93031 & 65 & 64 & 66 & 67 & 3.1 & 3.0 & 3.3 & 3.2 & 4.35 & 5.15 & 5.56 & 6.04 \\
\hline ICSA 88005 × ICSR 93001 & 65 & 66 & 66 & 66 & 2.2 & 2.4 & 2.3 & 2.3 & 6.32 & 5.16 & 5.34 & $6.46^{\mathrm{a}}$ \\
\hline ICSA $88005 \times$ ICSR 92003 & 63 & 64 & 69 & 70 & 2.1 & 2.3 & 2.3 & 2.4 & 4.98 & 6.26 & 5.69 & 5.56 \\
\hline ICSA $88005 \times$ ICSR 93031 & 62 & 62 & 63 & 63 & 2.8 & 2.9 & 3.2 & $3.0^{\mathrm{a}}$ & 5.71 & 5.78 & 4.42 & 4.77 \\
\hline Mean & $66^{\mathrm{b}}$ & 67 & 68 & 69 & 2.4 & 2.4 & 2.6 & 2.6 & 5.41 & 5.36 & 5.74 & 5.74 \\
\hline $\mathrm{CD}\left(\mathrm{A}_{1}-\mathrm{A}_{2}\right)(P=0.05)$ (at same levels $\mathrm{A}$ and $\mathrm{R}$ ) & 1.40 & & 1.42 & & 0.16 & & 0.15 & & 1.51 & & 0.82 & \\
\hline $\mathrm{CD}\left(\mathrm{A}_{1}-\mathrm{A}_{2}\right)(P=0.05)$ & 0.33 & & 0.34 & & 0.04 & & 0.04 & & 0.35 & & 0.19 & \\
\hline
\end{tabular}

\footnotetext{
${ }^{a}$ Significant cytoplasm differences in an individual hybrids

${ }^{\mathrm{b}}$ Significant cytoplasm differences over the average of all the hybrids
}

hybrids for grain yield. However, a perusal of pair-wise hybrids performance indicated significant cytoplasm differences for grain yield in a few nuclear genetic backgrounds. The hybrids such as ICSA $37 \times$ ICSR 93001, ICSA $37 \times$ ICSR 93031 and ICSA $42 \times$ ICSR 93031 in $\mathrm{A}_{1}$ CMS background were significantly superior to those in $\mathrm{A}_{2}$ CMS background during 2002 rainy season. On the other hand, two $\mathrm{A}_{2}$ CMS-based hybrids, ICSA $42 \times$ ICSR 93001 and ICSA $88005 \times$ ICSR 93001 were significantly superior to those based in $\mathrm{A}_{1}$ CMS system. Lee et al. (1992) and Moran and Rooney (2003) have also reported absence of significant cytoplasm differences (between $\mathrm{A}_{1}$ and $A_{3}$ and between $A_{1}, A_{2}$ and $A_{3}$ cytoplasms, respectively) for grain yield on the basis of average hybrids mean performance, but in pairwise comparison of individual hybrids, significant cytoplasm differences were detected in three hybrids. Such differential trends in cytoplasm differences in some of the iso-nuclear hybrids could be attributed to the interaction of cytoplasm with nuclear genes of A-lines and of Rlines in these hybrids. However, the distinction between cytoplasm effects and cytoplasm-nuclear interactions is complicated. This is not surprising considering that the very differentiation of CMS types is primarily based on the interaction of genes present on mitochondrial DNA and the corresponding nuclear restorer genes.

\section{Cytoplasm effects on sca effects}

Although, studies on the effects of cytoplasm on hybrid mean performance for various traits are useful, sca effects of iso-nuclear hybrids would be more revealing since they reflect differential interaction of cytoplasms with nuclear genes of A-lines as well as R-lines and it is this interaction in higher magnitude and desired direction that results in superior hybrid performance. While earliness was regarded as desired direction for 
days to $50 \%$ flowering, tall stature and higher magnitude for plant height and grain yield, respectively, were considered as desired directions. Specific combinations of A- and R-lines with good sca effects will remain the essential requirements for the production of superior hybrids (Duvick 1999). In the present study, though, most of both $\mathrm{A}_{1^{-}}$and $\mathrm{A}_{2}$-based hybrids showed significant sca effects for days to $50 \%$ flowering during 2001 rainy season, cytoplasm differences were absent in majority of the hybrids displaying significant $s c a$ effects (Table 5). Significant cytoplasm differences for sca effects for days to $50 \%$ flowering were evident only in three nuclear genetic backgrounds, ICSA $42 \times$ ICSR 93001, ICSA $42 \times$ ICSR 92003 and ICSA $42 \times$ ICSR 93031, although there was no definite pattern of association with a particular cytoplasm was observed. For example, while the hybrid ICSA $42 \times$ ICSR 93001 in $A_{1}$ background showed significant sca effect toward lateness, the same hybrid in $\mathrm{A}_{2}$ background showed significant sca effects toward earliness during 2001 rainy season. Another hybrid, ICSA $42 \times$ ICSR 92003 in both $\mathrm{A}_{1}$ and $\mathrm{A}_{2}$ backgrounds manifested significant sca effects toward earliness during 2001 rainy season with significant cytoplasm differences during 2001 rainy season. During 2002 rainy season, only a few hybrids manifested significant sca effects for days to $50 \%$ flowering within each of the cytoplasm backgrounds. However, cytoplasm differences were absent during 2002 rainy season.

None of the hybrids (except ICSA $88005 \times$ ICSR 93031 within $A_{2}$ cytoplasm during

Table 5 Estimates of sca effects of iso-nuclear sorghum hybrids as influenced by male-sterility inducing cytoplasm of their A-lines, 2001 and 2002 rainy seasons, ICRISAT, Patancheru

\begin{tabular}{|c|c|c|c|c|c|c|c|c|c|c|c|c|}
\hline \multirow[t]{3}{*}{ Hybrid } & \multicolumn{4}{|c|}{ Days to $50 \%$ flowering } & \multicolumn{4}{|c|}{ Plant height (m) } & \multicolumn{4}{|c|}{ Grain yield $\left(\mathrm{t} \mathrm{ha}^{-1}\right)$} \\
\hline & \multicolumn{2}{|l|}{2001} & \multicolumn{2}{|l|}{2002} & \multicolumn{2}{|l|}{2001} & \multicolumn{2}{|l|}{2002} & \multicolumn{2}{|l|}{2001} & \multicolumn{2}{|l|}{2002} \\
\hline & $\mathrm{A}_{1}$ & $\mathrm{~A}_{2}$ & $\mathrm{~A}_{1}$ & $\mathrm{~A}_{2}$ & $\mathrm{~A}_{1}$ & $\mathrm{~A}_{2}$ & $\mathrm{~A}_{1}$ & $\mathrm{~A}_{2}$ & $\mathrm{~A}_{1}$ & $\mathrm{~A}_{2}$ & $\mathrm{~A}_{1}$ & $\mathrm{~A}_{2}$ \\
\hline ICSA $17 \times$ ICSR 93001 & $0.85^{* *}$ & $0.19^{*}$ & -0.48 & 0.19 & -0.09 & -0.01 & -0.01 & $0.04^{\mathrm{a}}$ & -0.18 & -0.03 & -1.11 & -0.41 \\
\hline ICSA $17 \times$ ICSR 92003 & $0.24 * *$ & $1.57 * *$ & -0.76 & -1.09 & -0.02 & 0.06 & $0.062^{\mathrm{a}}$ & -0.05 & -0.03 & 0.04 & 0.84 & 0.44 \\
\hline ICSA $17 \times$ ICSR 93031 & $-1.09 * *$ & $-1.76^{* *}$ & 1.24 & 0.91 & 0.11 & -0.04 & -0.05 & $0.01^{\mathrm{a}}$ & 0.21 & -0.02 & 0.26 & -0.35 \\
\hline ICSA $37 \times$ ICSR 93001 & -0.04 & $0.52 * *$ & -0.48 & 0.52 & 0.01 & -0.07 & $-0.02^{\mathrm{a}}$ & -0.13 & -0.22 & -0.28 & 0.42 & -0.18 \\
\hline ICSA $37 \times$ ICSR 92003 & $0.69 * *$ & $0.57 * *$ & 1.24 & 0.24 & 0.01 & -0.03 & 0.00 & $0.11^{\mathrm{a}}$ & -0.41 & 0.02 & -0.02 & 0.67 \\
\hline ICSA $37 \times$ ICSR 93031 & $-0.65 * *$ & $-1.09 * *$ & -0.76 & -0.76 & -0.02 & 0.10 & 0.02 & 0.03 & 0.19 & 0.26 & -0.40 & -0.49 \\
\hline ICSA $38 \times$ ICSR 93001 & -0.04 & $0.41 * *$ & 0.63 & 0.74 & -0.03 & -0.01 & -0.05 & $0.09^{\mathrm{a}}$ & -0.21 & -0.32 & 0.18 & -0.10 \\
\hline ICSA $38 \times$ ICSR 92003 & $0.69 * *$ & $1.46^{* *}$ & -0.31 & 0.13 & 0.02 & 0.04 & $-0.01^{\mathrm{a}}$ & -0.12 & -0.08 & 0.08 & -0.19 & -0.32 \\
\hline ICSA $38 \times$ ICSR 93031 & $-0.65 * *$ & $-1.87 * *$ & -0.31 & -0.87 & 0.01 & -0.03 & 0.05 & 0.02 & 0.29 & 0.24 & 0.01 & 0.42 \\
\hline ICSA $42 \times$ ICSR 93001 & $0.85^{* *}$ & $-3.26 * * \mathrm{a}$ & -0.37 & -0.04 & 0.02 & -0.04 & -0.06 & -0.02 & 0.47 & 1.02 & -0.12 & 0.82 \\
\hline ICSA $42 \times$ ICSR 92003 & $-0.76^{* *}$ & $-5.20 * * \mathrm{a}$ & $-1.65^{*}$ & -0.31 & -0.03 & -0.05 & -0.08 & $-0.02^{\mathrm{a}}$ & 0.87 & 1.13 & -0.22 & 0.16 \\
\hline ICSA $42 \times$ ICSR 93031 & $-0.09^{\mathrm{a}}$ & $8.46^{* *}$ & $2.02 * *$ & 0.35 & 0.01 & 0.09 & $0.14^{\mathrm{a}}$ & 0.04 & $-1.35^{*}$ & $-2.15 * *$ & $0.34^{\mathrm{a}}$ & $-0.98 *$ \\
\hline $\begin{array}{l}\text { ICSA } 88001 \times \text { ICSR } \\
\quad 93001\end{array}$ & $-0.93 * *$ & $0.74 * *$ & -0.48 & -0.59 & 0.05 & 0.03 & 0.01 & -0.02 & -0.45 & 0.38 & -0.08 & 0.22 \\
\hline $\begin{array}{l}\text { ICSA } 88001 \times \text { ICSR } \\
\quad 92003\end{array}$ & $0.80 * *$ & $-0.54 * *$ & -0.43 & -0.54 & -0.13 & 0.00 & -0.02 & $0.05^{\mathrm{a}}$ & 0.19 & -0.85 & -0.04 & -0.86 \\
\hline $\begin{array}{l}\text { ICSA } 88001 \times \text { ICSR } \\
\quad 93031\end{array}$ & 0.13 & $-0.20 *$ & 0.91 & 1.13 & 0.08 & -0.02 & 0.01 & -0.03 & 0.26 & 0.48 & 0.12 & 0.64 \\
\hline $\begin{array}{l}\text { ICSA } 88005 \times \text { ICSR } \\
\quad 93001\end{array}$ & $0.41 * *$ & $0.30 * *$ & 0.30 & 0.07 & 0.07 & 0.07 & 0.08 & 0.09 & 0.30 & -0.92 & -0.16 & 0.51 \\
\hline $\begin{array}{l}\text { ICSA } 88005 \times \text { ICSR } \\
\quad 92003\end{array}$ & 0.13 & $0.35 * *$ & $1.69 *$ & $1.80 *$ & 0.07 & 0.07 & -0.02 & $0.84^{\mathrm{a}}$ & -1.09 & 0.12 & 0.05 & -0.52 \\
\hline $\begin{array}{l}\text { ICSA } 88005 \times \text { ICSR } \\
\quad 93031\end{array}$ & $-0.54 * *$ & $-0.65 * *$ & $-1.98 * *$ & $-1.87 *$ & -0.11 & -0.14 & $-0.06^{\mathrm{a}}$ & $-0.18^{*}$ & 0.79 & 0.79 & 0.11 & 0.01 \\
\hline $\mathrm{SE} \pm(\mathrm{Sij})$ & 0.09 & & 0.75 & & 0.08 & & 0.08 & & 0.62 & & 0.46 & \\
\hline $\mathrm{CD}\left(\mathrm{A}_{1}-\mathrm{A}_{2}\right)(P=0.05)$ & 2.59 & & 2.12 & & 0.22 & & 0.04 & & 1.73 & & 1.28 & \\
\hline
\end{tabular}

* Significant at $P=0.05$ level

** Significant at $P=0.01$ level

a Significant cytoplasm differences 
2002 rainy season) expressed significant sca effects for plant height within each of the cytoplasm backgrounds during both 2001 and 2002 rainy seasons. Significant cytoplasm differences were detected in ICSA $88005 \times$ ICSR 93031 during 2002 rainy season. Though significant cytoplasm differences were detected in four other nuclear genetic backgrounds, the differences do not assume importance, in view of the absence of significant $s c a$ effects of the hybrids within each of the cytoplasms for plant height during 2002 rainy season. Most of the hybrids in both $A_{1}$ and $A_{2}$ backgrounds failed to exhibit significant sca effects for grain yield. Significant cytoplasm differences were noticed in the only hybrid, ICSA $42 \times$ ICSR 93031 during 2002 rainy season, which showed significant sca effects for grain yield in both $\mathrm{A}_{1}$ and $\mathrm{A}_{2}$ CMS backgrounds during 2001 rainy season and in $\mathrm{A}_{2}$ CMS background during 2002 rainy season. These results suggested limited influence of cytoplasm on sca effects for all the three traits under study. The absence of cytoplasm-dependent sca effects is also evident from the occurrence of more or less equal frequency of $\mathrm{A}_{1}$ - and $\mathrm{A}_{2}$-based iso-nuclear hybrids that showed significant sca effects in desirable direction for plant height with a slight advantage of $\mathrm{A}_{2}$ over $\mathrm{A}_{1}$ for grain yield (Table 6). Williams-Alanis and Rodriguez-Herrera (1994b) also reported absence of cytoplasm effect on sca effects for grain yield.

\section{Cytoplasm effects on heterosis}

Even if the requirements of stability of CMS systems, availability of restorer genes in the germplasm and absence of adverse effects on economic traits are met, cytoplasmic effects on heterosis will ultimately determine the use of alternate CMS system for diversification of CMS-based hybrids. In general, mid-parent heterosis of $\mathrm{A}_{1}$ - and $\mathrm{A}_{2}$-based hybrids did not appear to differ significantly for any of the traits, when mid-parent heterosis of all the $\mathrm{A}_{1}$-based hybrids, as a group was compared to all the $A_{2}$-based hybrids as another group, as revealed by two-sample paired ' $t$ ' test (Table 7). However, when individual hybrids were examined, cytoplasm differences were apparent for mid-parent heterosis for only grain yield, though no definite trend favoring any particular cytoplasm was observed.

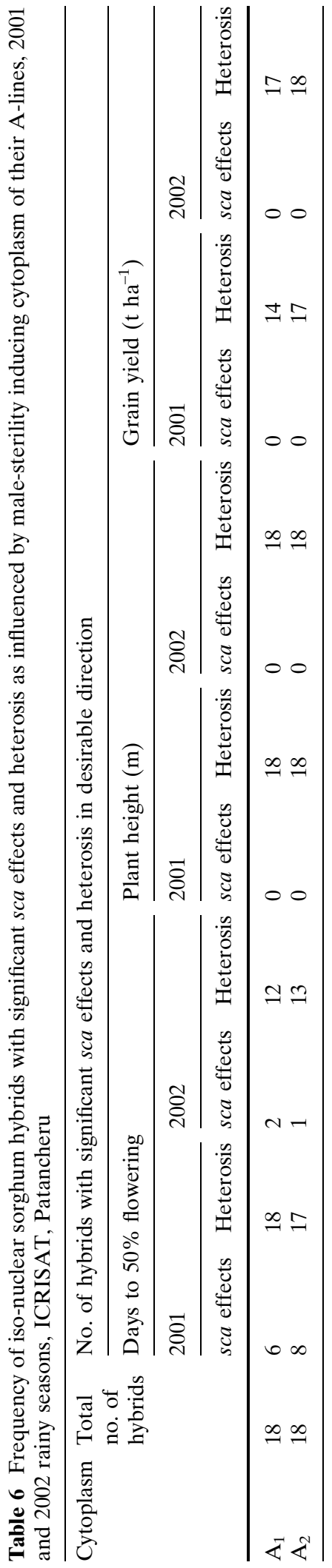


Table 7 Estimates of mid-parent heterosis of sorghum iso-nuclear hybrids as influenced by male-sterility inducing cytoplasm of their A-lines, 2001 and 2002 rainy seasons, ICRISAT, Patancheru

\begin{tabular}{|c|c|c|c|c|c|c|c|c|c|c|c|c|}
\hline \multirow[t]{3}{*}{ Hybrid } & \multicolumn{4}{|c|}{ Days to $50 \%$ flowering } & \multicolumn{4}{|c|}{ Plant height (m) } & \multicolumn{4}{|c|}{ Grain yield $\left(\mathrm{t} \mathrm{ha}^{-1}\right)$} \\
\hline & \multicolumn{2}{|l|}{2001} & \multicolumn{2}{|l|}{2002} & \multicolumn{2}{|l|}{2001} & \multicolumn{2}{|l|}{2002} & \multicolumn{2}{|l|}{2001} & \multicolumn{2}{|l|}{2002} \\
\hline & $\mathrm{A}_{1}$ & $\mathrm{~A}_{2}$ & $\mathrm{~A}_{1}$ & $\mathrm{~A}_{2}$ & $\mathrm{~A}_{1}$ & $\mathrm{~A}_{2}$ & $\mathrm{~A}_{1}$ & $\mathrm{~A}_{2}$ & $\mathrm{~A}_{1}$ & $\mathrm{~A}_{2}$ & $\mathrm{~A}_{1}$ & $\mathrm{~A}_{2}$ \\
\hline $\begin{array}{c}\text { ICSA } 17 \times \text { ICSR } \\
93001\end{array}$ & $-4.91 * *$ & $-4.45^{*}$ & $-3.55^{* *}$ & $-3.08 *$ & $28.54 * *$ & $28.54 * *$ & $39.38 * *$ & $43.83 * *$ & $57.94 * *$ & $50.61 *$ & 13.61 & $39.19 * *$ \\
\hline $\begin{array}{l}\text { ICSA } 17 \times \text { ICSR } \\
92003\end{array}$ & $-5.17 * *$ & $-5.17 * *$ & $-3.49 * *$ & $-4.41 * *$ & $34.29 * *$ & $30.41 * *$ & $38.14 * *$ & $31.95 * *$ & $42.49 * *$ & $43.67 * *$ & $70.54 * *$ & $68.06 * *$ \\
\hline $\begin{array}{l}\text { ICSA } 17 \times \text { ICSR } \\
93031\end{array}$ & $-7.11 * *$ & -3.78 & -2.39 & $-3.33^{*}$ & $20.19 * *$ & $20.19 * *$ & $47.95 * *$ & $51.22 * *$ & $55.21 * *$ & $46.20 * *$ & $62.90 * *$ & $63.12 * *$ \\
\hline $\begin{array}{l}\text { ICSA } 37 \times \text { ICSR } \\
93001\end{array}$ & $-8.79 * *$ & $-9.26 * *$ & $-3.49 * *$ & -0.70 & $19.60 * *$ & $17.75 * *$ & $45.53 * *$ & $40.00 * *$ & $46.44 * *$ & $41.02 * *$ & $56.44 * *$ & $25.81 * *$ \\
\hline $\begin{array}{l}\text { ICSA } 37 \times \text { ICSR } \\
92003\end{array}$ & $-8.44 * *$ & $-7.94 * *$ & -0.68 & -0.68 & $51.90 * *$ & $40.10 * *$ & $40.80 * *$ & $48.94 * *$ & $73.56^{* *}$ & $51.53 *$ & $52.56 * *$ & $51.19 * *$ \\
\hline $\begin{array}{c}\text { ICSA } 37 \times \text { ICSR } \\
93031\end{array}$ & $-7.25 * *$ & $11.12 * *$ & $-5.14 * *$ & $-3.74 * *$ & $45.14 * *$ & $49.15 * *$ & $56.41 * *$ & $58.06 * *$ & -10.89 & $-48.42 *$ & $46.47 * *$ & $21.23^{*}$ \\
\hline $\begin{array}{l}\text { ICSA } 38 \times \text { ICSR } \\
93001\end{array}$ & $-4.12^{*}$ & -2.75 & -0.23 & 0.23 & $31.34 * *$ & $29.37 * *$ & $36.89 * *$ & $45.29 * *$ & $58.99 * *$ & $46.47 * *$ & $49.29 * *$ & $40.48 * *$ \\
\hline $\begin{array}{l}\text { ICSA } 38 \times \text { ICSR } \\
\quad 92003\end{array}$ & $-5.91 * *$ & $-4.01 *$ & -1.14 & -0.23 & $22.15^{* *}$ & $20.39 * *$ & $33.99 * *$ & $27.18^{* *}$ & 23.98 & $60.94 * *$ & $51.66 * *$ & $41.22 * *$ \\
\hline $\begin{array}{c}\text { ICSA } 38 \times \text { ICSR } \\
93031\end{array}$ & $-4.40 *$ & $-3.94 *$ & $-2.82 *$ & $-3.30 *$ & $19.42 * *$ & $19.42 * *$ & $51.95 * *$ & $50.37 * *$ & $36.54^{*}$ & $48.17 * *$ & $62.91 * *$ & $65.99 * *$ \\
\hline $\begin{array}{l}\text { ICSA } 42 \times \text { ICSR } \\
93001\end{array}$ & $-4.79 * *$ & $-7.17 * *$ & $-3.08^{*}$ & $-3.08^{*}$ & $2.57 * *$ & $8.47 * *$ & $41.36 * *$ & $39.14 * *$ & $35.24^{*}$ & 23.79 & $25.28 * *$ & $58.89 * *$ \\
\hline $\begin{array}{l}\text { ICSA } 42 \times \text { ICSR } \\
92003\end{array}$ & $-5.65 * *$ & $-5.65 * *$ & $-4.41 * *$ & $-3.01^{*}$ & $42.02 * *$ & $50.20 * *$ & $33.99 * *$ & $33.99 * *$ & $60.60 * *$ & $63.91 * *$ & $33.39 * *$ & $52.51 * *$ \\
\hline $\begin{array}{l}\text { ICSA } 42 \times \text { ICSR } \\
\quad 93031\end{array}$ & $-5.11 * *$ & $-6.09 * *$ & -0.96 & $-3.81 * *$ & $36.31 * *$ & $31.11 * *$ & $60.33 * *$ & $52.38 * *$ & 40.91 & $66.88 * *$ & $49.89 * *$ & $20.68 * *$ \\
\hline $\begin{array}{l}\text { ICSA } \\
\quad 88001 \times \text { ICSR } \\
93001\end{array}$ & $-5.03 * *$ & $-6.85^{* *}$ & $-4.10 * *$ & $-4.10 * *$ & $24.88^{* *}$ & $31.73 * *$ & $29.00 * *$ & $25.24 * *$ & $33.79 *$ & $31.03 *$ & $31.00 * *$ & $35.90 * *$ \\
\hline $\begin{array}{l}\text { ICSA } \\
\quad 88001 \times \text { ICSR } \\
92003\end{array}$ & $-6.67 * *$ & $-6.19 * *$ & $-3.55^{* *}$ & $-3.55^{* *}$ & $27.6^{* *}$ & $35.26 * *$ & $23.51 * *$ & $25.23 * *$ & $76.04 * *$ & $44.01 *$ & $36.90 * *$ & $19.17 * *$ \\
\hline $\begin{array}{l}\text { ICSA } \\
\qquad 88001 \times \text { ICSR } \\
93031\end{array}$ & $-5.31 * *$ & $-6.7 * *$ & $-3.40^{*}$ & $-2.91 *$ & $16.27 * *$ & $22.80 * *$ & $40.43 * *$ & $37.57 * *$ & $32.08^{*}$ & $35.39 *$ & $41.51 * *$ & $53.70 * *$ \\
\hline $\begin{array}{l}\text { ICSA } \\
\quad 88005 \times \text { ICSR } \\
93001\end{array}$ & $-8.44 * *$ & $-7.47 * *$ & $-4.79 * *$ & $-4.79 * *$ & $16.33^{* *}$ & $23.64 * *$ & $52.19 * *$ & $47.88^{* *} *$ & 31.66 & $65.44 * *$ & $27.62 * *$ & $54.35^{* * *}$ \\
\hline $\begin{array}{l}\text { ICSA } \\
\quad 88005 \times \text { ICSR } \\
92003\end{array}$ & $-6.58 * *$ & $-10.8 * *$ & -2.35 & -1.87 & $39.76 * *$ & $42.99 * *$ & $39.99 * *$ & $41.01 * *$ & $44.72 *$ & $43.06^{*}$ & $33.92 * *$ & $35.77 * *$ \\
\hline $\begin{array}{l}\text { ICSA } \\
88005 \times \text { ICSR } \\
93031\end{array}$ & $-8.82 * *$ & $-8.34 * *$ & $-9.39 * *$ & $-8.91 * *$ & $29.90 * *$ & $36.99 * *$ & $52.38 * *$ & $42.86^{* *}$ & $100.00 * *$ & $102.45 * *$ & $42.38 * *$ & $53.61 * *$ \\
\hline $\begin{array}{l}\text { Two-sample } t \text {-test } \\
\text { (paired) } \\
\text { probability }\end{array}$ & 0.40 & & 0.47 & & 0.21 & & 0.33 & & 0.79 & & 0.88 & \\
\hline
\end{tabular}

* Significant at $P=0.05$ level

** Significant at $P=0.01$ level

For example, while the $\mathrm{A}_{2}$-based hybrids such as ICSA $38 \times$ ICSR 92003 and ICSA $42 \times$ ICSR 93031 showed greater mid-parent heterosis for grain yield than those based on $\mathrm{A}_{1}$ cytoplasm, reverse was true in case of the hybrids such as ICSA $37 \times$ ICSR 93001 and ICSA $88001 \times$ ICSR 92003 
during 2001 rainy season. Similarly, while a few $\mathrm{A}_{2}$ based hybrids such as ICSA $42 \times$ ICSR 93001, ICSA $42 \times$ ICSR 92003 and ICSA $88005 \times$ ICSR 93001 showed greater mid-parent heterosis for grain yield than those based on $\mathrm{A}_{1}$-based hybrids, reverse was true in case of the hybrids such as ICSA $37 \times$ ICSR 93001, ICSA $37 \times$ ICSR 93031 and ICSA $42 \times$ ICSR 93031 during 2002 rainy season. However, the magnitude and direction of midparent heterosis of $\mathrm{A}_{1}$ - and $\mathrm{A}_{2}$-based hybrids were comparable for days to $50 \%$ flowering and plant height during both 2001 and 2002 rainy seasons. It was interesting to note that the frequency of heterotic hybrids for days to $50 \%$ flowering, plant height and grain yield in desirable direction in $\mathrm{A}_{1}$ and $\mathrm{A}_{2}$ cytoplasm backgrounds were more or less comparable with a slight edge in favor of $\mathrm{A}_{2}$ for days to $50 \%$ flowering and grain yield (Table 6 ).

Thus, while there are significant cytoplasm effects on the expression in some of the nuclear genetic backgrounds of the hybrids, the magnitude of cytoplasm effects on gca effects of A-lines and on mean performance, sca effects and mid-parent heterosis of hybrids was small to have any practical significance. Further, magnitude of cytoplasm effects varied with the trait as well as with nuclear genetic backgrounds of A-lines and hybrid combinations depending on the interaction of cytoplasm with A- and R-lines, suggesting the need for assessing cytoplasm effects in diverse nuclear genetic backgrounds of A-lines as well as R-lines. The $\mathrm{A}_{2}$ cytoplasm appeared to be slightly more advantageous as far as the frequency of hybrids with significant sca effects and mid-parent heterosis for days to $50 \%$ flowering and grain yield were concerned. The results have also demonstrated that the use of gca effects of A-lines and hybrids mean performance, sca effects and heterosis criteria are complementary and not exclusive ways of discerning cytoplasm differences. The simultaneous use of multiple criteria will always be advantageous in such a study. It may, however, be noted that the line $\times$ tester analysis used in the study is on a fixed-effects model and the present results are applicable only to the material used in the study and some variation in the results might be observed if a different set of parents are evaluated.

\section{Conclusions}

The study, according to authors knowledge, is the first of its kind to assess the efficiency of $\mathrm{A}_{2}$ CMS systems in comparison to the widely used $\mathrm{A}_{1}$ system on all aspects of CMS-based sorghum hybrid cultivar development, i.e., cytoplasm effects on $g c a$ of A-lines and frequency of hybrids with high and significant sca effects and mid-parent heterosis using allo-plasmic, isonuclear $\mathrm{A}$-lines and dual $\left(\mathrm{A}_{1}\right.$ and $\left.\mathrm{A}_{2}\right)$ restorers. The results revealed that $\mathrm{A}_{2} \mathrm{CMS}$ system is comparable to the widely used $\mathrm{A}_{1}$ system for plant height with a slight advantage of $A_{2}$ in favor of $A_{1}$ in terms of frequency of hybrids with significant sca effects and mid-parent heterosis for days to $50 \%$ flowering and grain yield. Thus, considering the restoration frequency, development of high yielding A-lines using $\mathrm{A}_{1}$ restorers, and desirable gca effects of A-lines as well as mean performance, sca effects and heterosis of hybrids for economic traits such as grain yield, seed set (\%) upon selfing and open pollination, days to $50 \%$ flowering and plant height, it is as advantageous to use $\mathrm{A}_{2}$ CMS system as with $A_{1}$ CMS system among the alternate cytoplasms available. Moran and Rooney (2003) have also advocated $\mathrm{A}_{2}$ CMS system as the best among the available alternative cytoplasms. However, $\mathrm{A}_{2} \mathrm{CMS}$ system is not popular as the anthers in $\mathrm{A}_{2}$ male-sterile lines, unlike those of $\mathrm{A}_{1}$ male-sterile lines mimic the fertile or maintainer lines and lead to difficulties in monitoring the purity of hybrid in commercial seed production. Such difficulties can be overcome through appropriate training to those involved in hybrid seed production. China has already developed and released $\mathrm{A}_{2}$ cytoplasmbased hybrids for commercial cultivation (Shan et al. 2000). Extensive research is underway at ICRISAT, India and elsewhere for the development of $\mathrm{A}_{2}$ cytoplasm-based hybrids.

Acknowledgments Generous financial grants from ICRISAT-Private Sector Sorghum Hybrids Parents Research Consortium and Sehgal Family Foundation for partial support for conducting this research is greatly acknowledged. We also acknowledge the assistance of Ms Rupa, Scientific Officer, for statistical analysis of the experimental data. 


\section{References}

Annicchiarico P (2002) Genotype $\times$ environment interaction-challenges and opportunities for plant breeding and cultivar recommendations. FAO Plant Production and Protection Paper, Food and Agriculture Organization of the United Nations, Rome, 115 pp

Bartlett MS (1937) Some examples of statistical methods of research in agriculture and applied biology. J R Stat Soc 4:137-170

Bhavsar VV, Borikar ST (2002) Combining ability studies in sorghum involving diverse cytosteriles. J Maharashtra Agric Univ 27:35

Deb UK, Bantilan MCS, Evenson RE, Roy AD (2004) Productivity impacts of improved sorghum cultivars. In: Bantilan MCS, Deb UK, Gowda CLL, Reddy BVS, Obilana AB, Evenson RE (eds) Sorghum genetic enhancement: research process, dissemination and impacts. International Crops Research Institute for the Semi-Arid Tropics, Patancheru, Andhra Pradesh, India, pp 203-222

Duvick DN (1999) Heterosis: feeding people and protecting natural resources. In: Coors JG, Pandey S (eds) Genetics and exploitation of heterosis in crops. ASACSSA-SSSA, Madison, pp. 19-29

Kempthorne O (1957) An introduction to genetic statistics. Wiley, New York

Kishan AG, Borikar ST (1988) Heterosis and combining ability in relation to cytoplasmic diversity in sorghum (Sorghum bicolor). Indian J Agric Sci 58:715-717

Kishan AG, Borikar ST (1989) Genetic relationship between some cytoplasmic male sterility systems in sorghum. Euphytica 4:259-269

Lee RD, Johnson BE, Eskridge KM, Pedersen JF (1992) Selection of superior female parents in sorghum utilizing $\mathrm{A}_{3}$ cytoplasm. Crop Sci 32:918-921

Maves AJ, Atkins RE (1988) Agronomic performance of sorghum hybrids produced by using different malesterility-inducing cytoplasms. J Iowa Acad Sci 95:43-46

Moran JL, Rooney WL (2003) Effect of cytoplasm on the agronomic performance of grain sorghum hybrids. Crop Sci 43:777-781

Murty UR (1991) National programme on sorghum research in India. Paper presented at the consultative meeting to consider establishment of regional sorghum research network for Asia, 16-19 September 1991.International Crops Research Institute for the Semi-Arid Tropics, Patancheru, Andhra Pradesh, India

Murty UR (1992) ICAR-ICRISAT collaborative research projects-Sorghum Progress Report. National Research Center for Sorghum, Hyderabad, India, pp 27

Quinby JR, Karper RE (1946) Heterosis in sorghum resulting from the heterozygous condition of a single gene that affects duration of growth. Am J Bot 33:716

Rana BS, Murty BR (1978) Role of height and panicle type in yield heterosis in some grain sorghum. Indian $\mathrm{J}$ Genet 38:126-134
Rana BS, Jaya Mohan Rao V, Reddy BB, Rao NGP (1985) Overcoming present hybrid yield in sorghum. In: Proceedings of pre-congress symposium XV international genetics congress on genetics of heterotic system in crop plants, 7-9 December 1983. Tamil Nadu Agricultural University, Coimbatore, India, pp 48-59

Rao NGP (1970) Genetic analysis of some exotic $\times$ Indian crosses in sorghum. 1. Heterosis and its interaction with seasons. Indian J Genet 30:347-361

Reddy BVS, Ramesh S, Ortiz R (2005) Genetic and cytoplasmic-nuclear male sterility in sorghum. Plant Breed Rev 25:139-172

Rodriguez-Herrera RH, Torres-Montalvo, Williams-Alanis $\mathrm{H}$ (1993) Comparative performance of maintainer and male-sterile sorghum isogenic lines in $A_{1}$ and $A_{2}$ cytoplasms. Sorghum Newsl 34:50

Schertz KF (1994) Male-sterility in sorghum: its characteristics and importance. In: Witcombe JR, Duncan RR (eds) Use of molecular markers in sorghum and pearl millet breeding for developing countries. Proceedings of the international conference genetic improvement. Overseas Development Administration (ODA) plant sciences research conference, 29 March1 April 1993. ODA, Norwich, UK, pp 35-37

Schertz KF, Ritchey JM (1978) Cytoplasmic-genic malesterility systems in sorghum. Crop Sci 18:890-893

Secrist RE, Atkins RE (1989) Pollen fertility and agronomic performance of sorghum hybrids with different male-sterility inducing cytoplasms. J Iowa Acad Sci 96:99-103

Shan LQ, Ai PJ, Yin LT, Yao ZF (2000) New grain sorghum cytoplasmic male-sterile line $\mathrm{A}_{2} \mathrm{~V}_{4} \mathrm{~A}$ and $\mathrm{F}_{1}$ hybrid Jinza No. 12 for Northwest China. Int Sorghum Millets Newsl 41:31-32

Shinde VK, Nandanwankar KG, Ambekar SS (1983) Heterosis and combining ability for grain yield in rabi sorghum. Sorghum Newsl 26:19

Stephens JC, Holland PF (1954) Cytoplasmic male sterility for hybrid sorghum seed production. Agron J 46:20-23

Tatum LA (1971) The southern corn leaf blight epidemic. Science 171:1113-1116

Williams-Alanis H, Rodriguez-Herrera R (1992) Cytoplasmic-genic male-sterility effect in flowering of sorghum isogenic lines. Sorghum Newsl 33:17

Williams-Alanis H, Rodriguez-Herrera R (1994a) Comparative performance of sorghums in $A_{1}$ and $A_{2}$ cytoplasms. II. Yield and agronomic characteristics. Cereal Res Commun 22(4):301-307

Williams-Alanis H, Rodriguez-Herrera R (1994b) Combining ability on isogenic sorghums in $A_{1}$ and $A_{2}$ cytoplasms. Int Sorghum Millets Newsl 35:75

Williams-Alanis H, Rodriguez-Herrera R, Aguirre-Rodriguez J, Torres-Montalvo H (1993) Comparative performance of isogenic sorghum hybrids in $\mathrm{A}_{1}$ and $\mathrm{A}_{2}$ cytoplasms. II. Yield and agronomic characteristics. Sorghum Newsl 34:51 